\title{
МЕХАНІЗМИ ЗАБЕЗПЕЧЕННЯ РОЗВИТКУ ІННОВАЦІЙНИХ ПРОЦЕСІВ ТА ЕКОНОМІЧНОЇ БЕЗПЕКИ ЩОДО ФОРМУВАННЯ ІНФРАСТРУКТУРИ ДНІПРОВСЬКОГО РЕГІОНУ
}

\section{MECHANISMS OF ENSURING THE DEVELOPMENT OF INNOVATIVE PROCESSES AND ECONOMIC SECURITY OF INFRASTRUCTURE FORMATION OF THE DNIPRO REGION}

\author{
Кравченко Микола Володимирович \\ доктор економічних наук, доцент, \\ Дніпровський державний аграрно-економічний університет \\ ORCID: https://orcid.org/0000-0002-6942-0914 \\ Kravchenko Mykola \\ Dnipro State Agrarian and Economic University
}

\begin{abstract}
В статті обґрунтуванно теоретико-методичні і практичні положення, спрямовані на інвестиційно-інноваційну діяльність Дніпропетровської обласної державної адміністрації щодо фрормування інфраструктури регіону в умовах децентралізації. Відповідно до зазначеного було розглянуто теоретико-методичні аспекти інвестиційно-інноваційної діяльності обласної державної адміністрації щодо формування інфраструктури регіону в умовах децентралізації; проаналізовано сучасний стан залучення інвестицій у розвиток інсрраструктури регіону; виділено завдання та заходи залучення інвестицій щодо фрормування інсрраструктури регіону; визначено перспективи залучення інвестицій у розвиток інфраструктури регіону; обґрунтовано цільові установки управління інвестиційно-інноваційною діяльності обласної державної адміністрації щодо формування інфраструктури регіону в умовах децентралізації; запропоновано державно-приватне партнерство як інструмент залучення інвестицій у розвиток інфрраструктури регіонів; визначено механізми забезпечення розвитку інноваційних процесів щодо фрормування інфрраструктури регіону.
\end{abstract}

Ключові слова: інвестиції, інновації, економічна безпека, стратегія, регіон, інтеграція.

В статье обоснованно теоретико-методические и практические положения, направленные на инвестиционно-инновационную деятельность Днепропетровской областной государственной администрации по фрормированию инфраструктуры региона в условиях децентрализации. Согласно указанному были рассмотрены теоретико-методические аспекты инвестиционно-инновационной деятельности областной государственной администрации по формированию инораструктуры региона в условиях децентрализации; проанализировано современное состояние привлечения инвестиций в развитие инфраструктуры региона; выделены задачи и мероприятия привлечения инвестиций по формированию инфраструктуры региона; определены перспективы привлечения инвестиций в развитие инфраструктуры региона; обоснованы целевые установки управления инвестиционно-инновационной деятельности областной государственной администрации по формированию инфраструктуры региона в условиях децентрализации; предложено государственно-частное партнерство как инструмент привлечения инвестиций в развитие инфраструктуры регионов; определены механизмы обеспечения развития инновационных процессов по фрормированию инфраструктуры региона.

Ключевые слова. инвестиции, инновации, экономическая безопасность, стратегия, регион, интеграция.

The article substantiates the theoretical, methodological and practical provisions aimed at investment and innovation activities of the Dnipropetrovsk Regional State Administration on the formation of the region's infrastructure in the context of decentralization. In accordance with the above, the theoretical and methodological aspects of investment and innovation activities of the regional state administration on the formation of the region's infrastructure in the context of decentralization were considered; the current state of attracting investments in the development of the region's infrastructure is analyzed; tasks and measures of attraction of investments concerning formation of 
infrastructure of the region are allocated; the prospects of attracting investments in the development of the region's infrastructure are determined; the target installations of management of investment and innovation activity of the regional state administration concerning formation of infrastructure of the region in the conditions of decentralization are substantiated; public-private partnership is proposed as a tool to attract investment in the development of regional infrastructure; mechanisms for ensuring the development of innovative processes for the formation of the region's infrastructure have been identified. In modern conditions, the impact of destabilizing factors of the external and internal environment is extremely acute, which requires special attention to the study of the problems of strengthening the economic security of the agricultural sector through territorial production systems. The mechanism of interaction between the government and agrarian business in the field of strengthening the economic security of the agricultural sector in foreign countries has been implemented for a long time and is constantly being improved. Socially significant problems, taking into account the growing needs of the population, remain a priority for the mechanism of public-private partnership and are addressed to strengthen the economic security of the agricultural sector. A distinctive feature of the interaction between government and business is how effectively state institutions and management of agrarian business can prevent internal and external threats and eliminate the harmful effects of certain negative components of the external and internal environment. The study is to conduct a detailed scientific and practical substantiation of ways to strengthen the economic security of the agricultural sector with the help of territorial production systems in Ukraine and identify areas for improvement of this sector of the economy.

Keywords: agrarian sector, agrarian business, economic security, territorial production systems, integration.

Постановка проблеми. Стан інфрраструктурної сорери регіонів, як сукупність об'єктів економічної та соціальної інфрраструктури, розташованих на території регіону і забезпечують безперебійне і есрективне срункціонування регіональної економіки в цілому і життєдіяльності людей зокрема) надає істотний вплив на конкурентоспроможність регіональної економіки. Крім того, рівень розвитку інсрраструктури зумовлює передумови, швидкість і якість переходу країн й регіонів в новий технологічний уклад. Відсутність розвинених і ефективно фрункціонуючих об'єктів інфрраструктури в регіонах призводить до істотного стримування можливостей зниження собівартості, зростання транзакційних витрат суб'єктів господарювання та обмежує можливості залучення інвестицій в регіональну економіку.

Розвиток інфрраструктурної ссрери регіонів знаходиться в прямій залежності від обсягів та інтенсивності залучення в неї інвестицій. При цьому в силу значної капіталомісткості, ризикованості та тривалості строків окупності приватний капітал, як правило, дуже обережно включається в реалізацію інфраструктурних проектів. 3 іншого боку, обмеженість бюджетних ресурсів переважної більшості регіонів України, а також проблеми, пов'язані з якістю державного управління на регіональному та муніципальному рівнях при реалізації складних інноваційних проектів в інсрраструктурній ссрері, стримують можливості вирішення багатьох принципових регіональних соціально-економічних питань. В результаті відбувається істотне зниження темпів розвитку інфрраструктурної ссрери регіонів. Останнє, в свою чергу, об'єктивно веде до уповільнення зростання конкурентоспроможності регіонів і країни в цілому, а також створює передумови для виштовхування ії на перифрерію світової економіки.

Аналіз останніх досліджень і публікацій. Значний внесок у розвиток теоретичних і практичних аспектів регіональної інвестиційно-інноваційної політики щодо фрормування інфраструктури регіону зробили такі вітчизняні вчені: Бахматюк О.Р., Веретенникова О.В., Дегтярьов А.В., Комарницька Г.О., Комашенко Т.А., Косач І.А., Куриляк М.Ю., Лещук Г.В., Мартьянов М.П., Омельянович Л.О., Руденко О.Ю., Федоренко В.Г., Фірсов Д.В. та ін.

Разом з тим, питання організації, методики і практики процесу інвестиційно-інноваційної діяльності щодо фрормування інфраструктури регіону досліджені недостатньо. Багато теоретичних розробок до сих пір не застосовуються в практичній діяльності. Дискусійними залишаються питання сутності та змісту інвестиційної діяльності обласної державної адміністрації, питання щодо фрормування організаційно-економічних механізмів забезпечення розвитку інноваційних процесів щодо соормування інфрраструктури регіону.

Також вплинули на генезис та зміцнення економічної безпеки даного сектора економіки у своїх працях висвітлювали Aleksy Kwilinski A., Pajak K., Stewart F., Kotler Ph., Porter M., Shumpeter J., Stachowiak Z., Verrier B., Rose B., Zhou M.

Мета дослідження. Обґрунтування теоретико-методичних і практичних положень, спрямованих на інвестиційно-інноваційну діяльність обласної державної адміністрації щодо срормування інфрраструктури та економічної безпеки регіону в умовах децентралізації. 
Виклад основного матеріалу. Досягнення цільових орієнтирів, передбачених Проєктом Закону України «Про Стратегію сталого розвитку України до 2030 року» передбачає перехід на інноваційний соціально-орієнтований тип економічного розвитку країни. У цих умовах головним джерелом економічного зростання стають інвестиції.

У Законі України «Про інвестиційну діяльність» від 18 вересня 1991 р. № 1560-XII інвестиції трактуються як «всі види майнових та інтелектуальних цінностей, що вкладаються в об'єкти підприємницької та інших видів діяльності, в результаті якої створюється прибуток (доход) та/або досягається соціальний та екологічний ефект» [1, с. 7-10].

Для здійснення інвестицій необхідні інвестиційні ресурси, що представляють собою всі види фрінансових активів, які залучаються для здійснення вкладень в об'єкти інвестування.

Вони трансформуються в об'єкт інвестиційної діяльності, що дає початок здійсненню інвестиційного процесу, який, в свою чергу, визначає інвестиційну активність, що характеризує інтенсивність залучення інвестицій в основний капітал. Регіон володіє певними природними, матеріальними, фрінансовими ресурсами, які фрормують інвестиційний потенціал регіону. Інвестиційний потенціал і срактори ризику визначають інвестиційну привабливість, яка оцінюється за двома параметрами: інвестиційний потенціал та інвестиційний ризик. Потенціал показує, яку частку регіон займає на загальноукраїнському ринку, ризик - якими можуть виявитися для інвестора масштаби тих чи інших проблем в регіоні [3, с. 59-65].

Інвестиційна активність разом 3 інвестиційною привабливістю фрормує інвестиційний клімат території. Напрямки щодо поліпшення інвестиційного клімату регіону знаходять відображення в інвестиційній політиці (рис. 1).

Дослідження теорії інвестицій показало, що інвестиції направляються або в фрізичний капітал, або в людський капітал, або в сектор знань. Огляд існуючих трактувань інвестицій свідчить про те, що єдиного визначення даного поняття не існує, проте всі автори згодні з тим, що інвестиції $€$ одним 3 найважливіших інструментів економічного зростання країни, а управління ними - однією з актуальних завдань національної економіки.

Інструментом управління інвестиціями виступає інвестиційна політика, модель якої залежить від обраної економічної теорії, адаптованої до сучасного етапу соціальноекономічного розвитку території. Вона $€$ основою переходу на інноваційний шлях розвитку.

Цілі регіональної інвестиційно-інноваційної політики в різних сорерах економічного життя мають свою специоріку, яка обумовлена дією чинників, властивих сучасній російській економіці [5, с. 67-70].

Державне регулювання та підтримка інноваційної діяльності в розрізі регіонів проводиться за конкретними напрямами на основі використання певних механізмів і методів реалізації. Провести безпосередню аналогію між

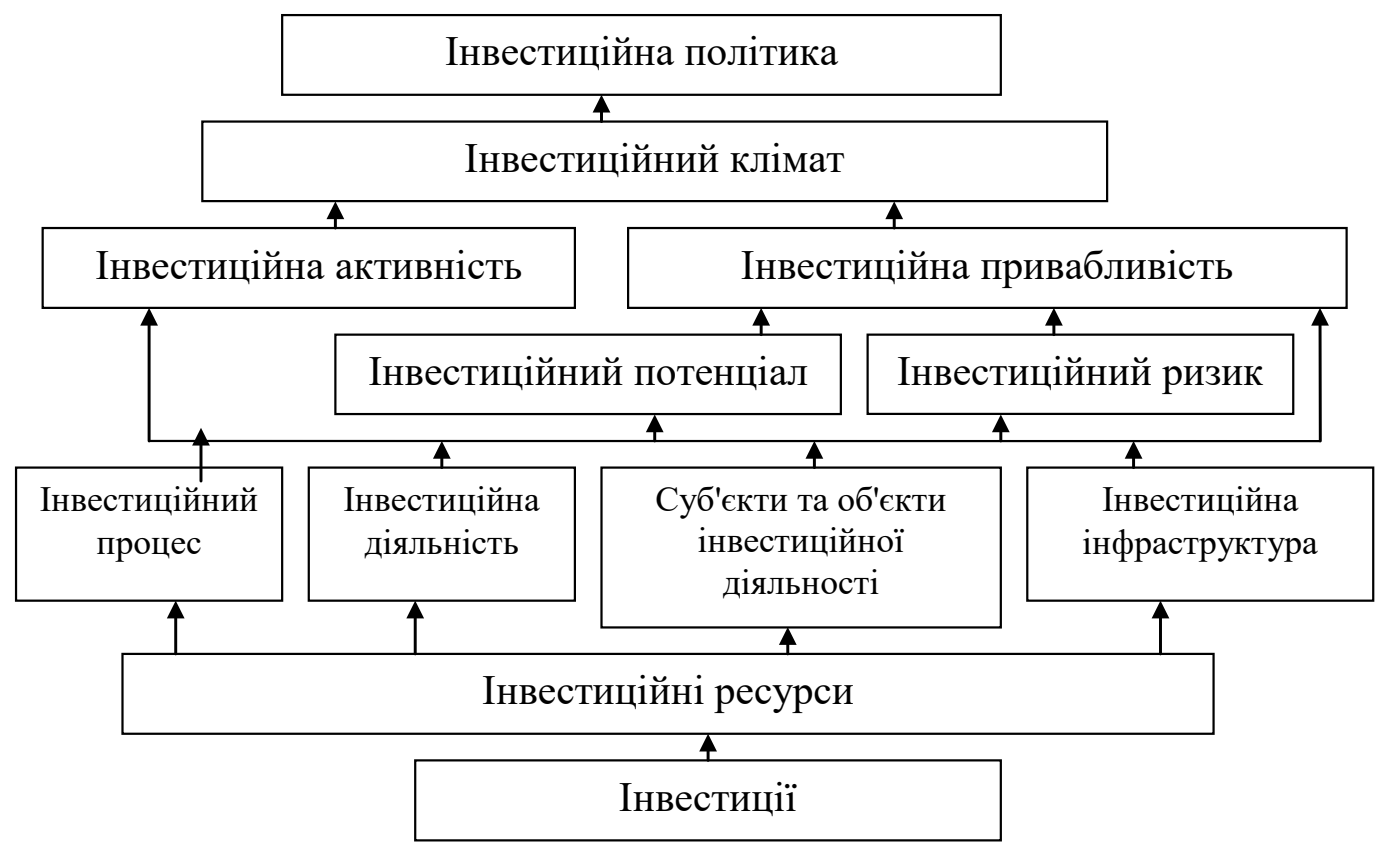

Рис. 1. Піраміда взаємозв'язку базових понять в сфері інвестицій 
регіоном і підприємством важко, проте дослідження підходів до відкриття змісту і дефрініції визначення стратегії підприємства для визначення інноваційної стратегії регіону є необхідним. Необхідно відзначити, що результативна дія ринкового механізму державного регулювання і підтримки інноваційного процесу в регіоні створюється присутність повної інноваційної підприємницької діяльності. Погоджуючись 3 судженнями вчених, рівень державного регулювання інноваційної діяльності зменшується після подолання кризи і розвитку інноваційного підприємництва. Керуючись цим, ми вважаємо, що для підтримки та фрормування інноваційного підприємництва в сорері регіонів і міст необхідно, без сумніву, створити концепцію організаційно-економічного механізму фрормування та державного регулювання інноваційного підприємництва в регіоні країни.

Одним з основних завдань переходу економіки на інноваційний підхід формування вважається область високих технологій, в середу інноваційної діяльності від переходу нашої індустрії в технологічну націленість, яка дає можливість стрімко примножити конкурентоспроможність економічного потенціалу через результат зростання ії̈ порівняльних здібностей в науці, високих технологіях і освіті, а крім того збільшити добробут і на цій основі використовувати новітні джерела економічного та фрінансового зростання.

Об'єктивна особливість інноваційних процесів обумовлюється значним інтересом загальнодержавної інноваційної політики: істотної капіталоємністю наукових досліджень як головний інструментальний механізм згідно фрормуванню інновацій, значним ступенем ризику, значними умовами науково-технічної кваліфрікації кадрів і фрахівців, зв'язком 3 рівнем формування наукової сорери та інноваційної інфрраструктури тощо . Удосконалення інфрраструктури та посилення інвестиційної атмоссрери враховують надання здібностей 3 метою чесної конкуренції та фрормування підприємництва, що має бути основною метою державного стимулювання. Значною фрормі цей результат пов'язаний із закінченням єдиної програми виконання структурних реформ.

Досвід зарубіжних країн свідчить, що в державне регулювання $€$ всі шанси ввести ринкові механізми, проекти і виконавців, широке залучення індивідуальних грошових коштів, мотивації за допомогою змагання ідей, перемішаних механізмів фрінансування. Незважаючи на це, держава розробляє концепцію стиму- лювання за своєчасне здійснення державних заявок, а крім того відстоює загальнонаціональні пріоритети і цінності [6, с. 141-150].

Зарубіжні країни виявляють результативне вплив на економічну життєдіяльність суспільства. У зарубіжних державах, частина державних організацій має тенденцією зменшення, частина індивідуального капіталу і змішаного майна зростає. Розвиток і фрормування власного сектора відбувається державою за сприяння фрормування системи контрактних відносин.

Слід зазначити, що стратегічно обдумана політика країни в здійсненні механізму управління процесами розвитку інноваційного потенціалу активізує результативність і збільшення ринкових сил в економіці, активізує нові можливості для інноваційного зростання. Механізм управління процесами розвитку інноваційного потенціалу містить наступні ключові твердження:

- інноваційні процеси перебувають у безперервній зміні і пересуванні, система управління ними являє собою загальне, в якому всі процеси взаємопов'язані друг від друга;

- управління інноваційними процесами розвитку і фрормування інноваційного потенціалу носити собою внутрішніми протиріччями, які виражаються між колишнім і новітнім;

- управління процесами розвитку інноваційного потенціалу виконується в організаційних змінах, що характеризуються конкретною стійкістю;

- система управління процесами розвитку інноваційного потенціалу гарантує активну і відповідне формування і розвиток економіки;

- трансформація до прогресивних способів, що базуються на знанні і застосуванні існуючих ймовірних здібностей.

Реально діюча система управління процесами розвитку інноваційного потенціалу постійно регульована, так як орієнтована на результат певних цілей за допомогою впливу на конкретні чинники, що використовують існуючі ресурси.

Створення правової, податкової та адміністративної середовища, формування нових робочих зон і збільшення добробуту залучених в різноманітні пласти населення, сприяють активізації інноваційного підприємництва залежить від державної підтримки інноваційної підприємницької діяльності.

За цим слід вирішення певних організаційних завдань для того, щоб збільшити результативність застосування наявних розробок і досліджень. Реалізація стимулювання 
інноваційної діяльності має містити в собі здійснення ффундаментальних досліджень і розширюватися для всіх інвесторів в стадії життєвого циклу дослідження та виробництва наукомісткого продукту, крім цього, фрормувати позитивну економічну атмоссреру, що стимулює інтерес про впровадження науковотехнічних наслідків і надходження інвестицій в основний капітал, законодавчу службу охорони прав інтелектуальному майні, гарантувати сукупність заходів, що містять спрямовану підтримку пріоритетних напрямів інноваційної діяльності в різних областях. 3 метою досягнення встановлених завдань нами запропоновані абсолютно новітні ідеї до реалізації інноваційного процесу, який становить від настройки до базисної основи управління економіки в умовах переходу до інноваційного суспільства та інноваційного розвитку економіки (табл. 1).

Забезпечення зростання ВВП сприяє розвитку нових технологічних укладів, фрормуванню науково-технічного потенціалу в секторах економіки та зростанню конкурентоспроможності продукту. Виділимо активну інноваційну політику господарюючих суб'єктів, що виражається у вивченні виробництва свідомо новітніх різновидів продукту і технологій, в розширенні в даній базі ринків збуту продуктів.

Для регулювання інноваційного середовища виникає необхідність формування таких організаційних механізмів як інноваційно-технологічні центри, державні наукові центри, центри передачі технологій та інші.

В даний час стратегічні розробки отримали досить широке поширення в економіці регіону. Практично кожне підприємство регіону має свої плани стратегічного розвитку. Однак багато планів часто представляють результат механічного з'єднання традиційних знань 3 формальними вимогами і елементами сучасного підходу. Але ці формальні підходи при розробці планів стратегічного розвитку багато в чому пояснюються високим рівнем домінування централізованих методів у прийнятті рішень.

Для того, щоб стратегічне планування набуло характеру фрункціональної діяльності, воно повинно бути вбудовано у відповідні інститути управління, які забезпечують розробку й реалізацію планів або програм шляхом партнерської взаємодії всіх діючих систем. Ясно, що вирішення цього завдання можливе в рамках системного підходу і прийняття методичного підходу (навіть і нормативного акту) до розробки та реалізації стратегії розвитку інноваційних процесів щодо орормування інорраструктури регіону. У зв'язку з цим, пропонуємо наступні взаємопов'язані принципи розробки ефрективної стратегії розвитку інноваційних процесів щодо фрормування інфрраструктури регіону, яка заснована на системному підході (рис. 2).

Такий комплексний підхід, що включає організаційно-правові, економічні методи і форми досягнення цілей, може послужити конструктивною основою для розробки і реалізації стратегії інноваційного розвитку промислової системи регіону.

Результати. Визначено, що структурними елементами регіональної інвестиційно-інноваційної політики є: суб'єкти, об'єкт, цілі, принципи, області взаємодії держави з іншими учасниками процесу реалізації політики, стратегія (напрямки), інструменти та їх комбінації, що фрормують механізм реалізації стратегії; основні ефректи, заплановані від ії реалізації. Зміст регіональної інвестиційної політики розкриває запропонована модель фрормування регіональної інвестиційної політики щодо орормування інфрраструктури Дніпровського регіону в умовах децентралізації.

Висновки. В результаті проведеного дослідження було визначено, що інвестиції

\section{Механізми формування і розвитку інноваційних процесів щодо форомування інфраструктури регіону}

Таблиця 1

\begin{tabular}{|l|l|}
\hline \multicolumn{1}{|c|}{$\begin{array}{c}\text { Напрями інноваційного } \\
\text { розвитку }\end{array}$} & \multicolumn{1}{c|}{ Механізми } \\
\hline Наукова концепція & $\begin{array}{l}\text { Підвищення конкурентоспроможності регіону на основі } \\
\text { системного інтегрованого розвитку }\end{array}$ \\
\hline $\begin{array}{l}\text { Розвиток елементів } \\
\text { індраструктури }\end{array}$ & $\begin{array}{l}\text { Технологічні парки, бізнес, інкубатори, венчурні та } \\
\text { спеціалізовані фронди }\end{array}$ \\
\hline $\begin{array}{l}\text { Основні агенти інноваційної } \\
\text { системи }\end{array}$ & $\begin{array}{l}\text { Університети, заклади просресійно-технічної освіти, науково- } \\
\text { дослідні центри тощо. }\end{array}$ \\
\hline $\begin{array}{l}\text { Розвиток рівня транссрерту } \\
\text { інновації }\end{array}$ & $\begin{array}{l}\text { Зовнішньоекономічний комплекс, промислові зони, вільні } \\
\text { економічні зони тощо. }\end{array}$ \\
\hline
\end{tabular}




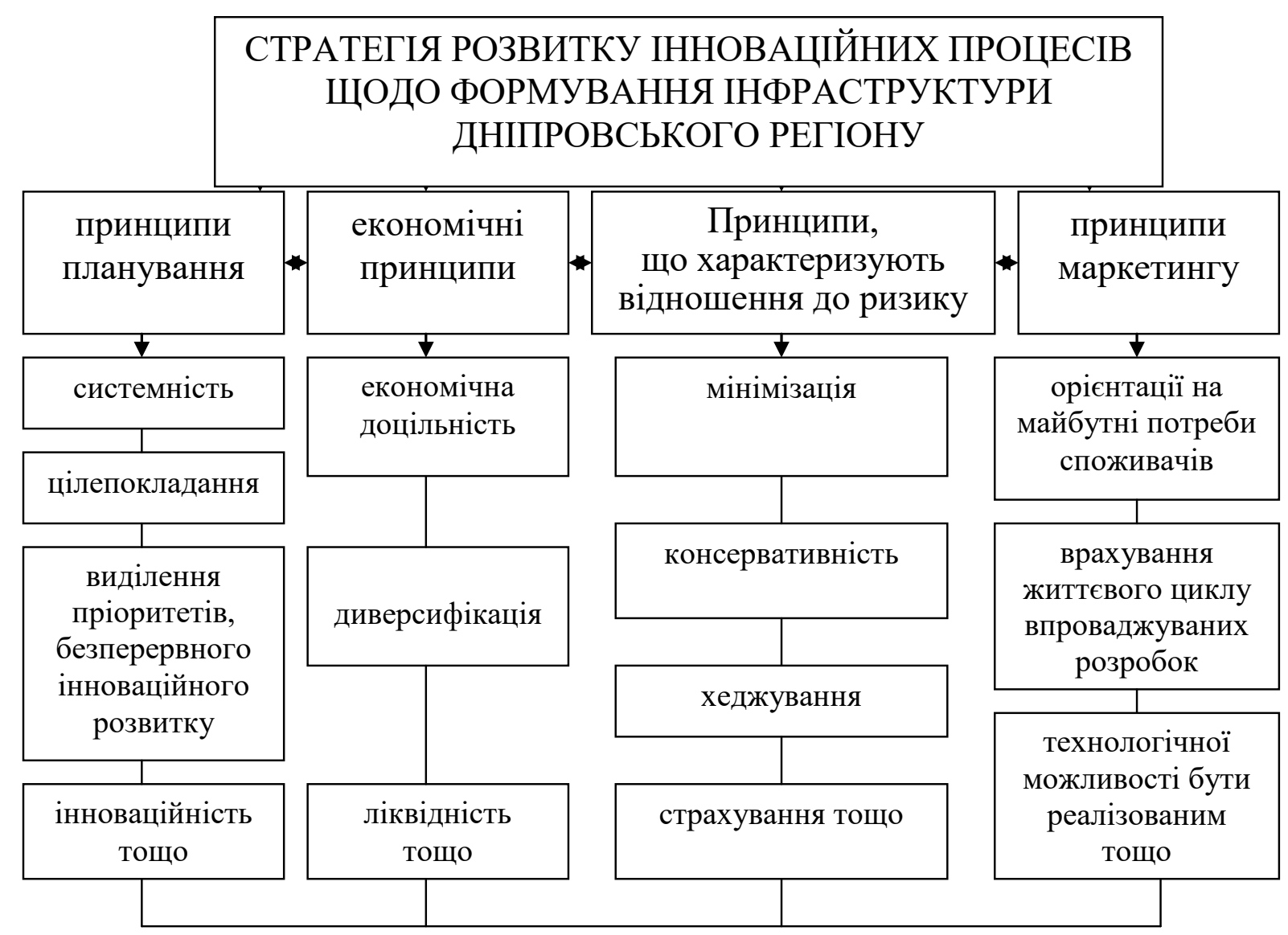

Рис. 2. Система взаємопов'язаних принципів розробки стратегії розвитку інноваційних процесів щодо формування інфраструктури Дніпровського регіону

направляються або в фрізичний капітал, або в людський капітал, або в сектор знань. Огляд існуючих трактувань інвестицій свідчить про те, що єдиного визначення даного поняття не існує, проте всі автори згодні з тим, що інвестиції $€$ одним 3 найважливіших інструментів економічного зростання країни, а управління ними - однією з актуальних завдань національної економіки. Інструментом управління інвестиціями виступає інвестиційна політика, модель якої залежить від обраної економічної теорії, адаптованої до сучасного етапу соціально-економічного розвитку території. Вона $€$ основою переходу на інноваційний шлях розвитку.

Для того, щоб стратегічне планування набуло характеру фрункціональної діяльності, воно повинно бути вбудовано у відповідні інститути управління, які забезпечують розробку й реалізацію планів або програм шляхом партнерської взаємодії всіх діючих систем. Вирішення цього завдання можливе в рамках системного підходу і прийняття методичного підходу (навіть і нормативного акту) до розробки та реалізації стратегії розвитку інноваційних процесів щодо фрормування інфрраструктури регіону. У зв'язку з цим, запропоновано взаємопов'язані принципи розробки есрективної стратегії розвитку інноваційних процесів щодо формування інфрраструктури регіону, яка заснована на системному підході. Такий комплексні підхід, що включає організаційно-правові, економічні методи і фрорми досягнення цілей, можуть послужити конструктивною основою для розробки та реалізації стратегії інноваційного розвитку регіону.

Існує прямий зв'язок між можливостями того чи іншого регіону щодо прискореного економічного розвитку, залучення іноземних інвестицій та стану його інфрраструктури. сучасний підхід у фрормуванні ефрективного регіонального інфрраструктурного середовища для країн із ринковою економікою включає в себе наступні стандарти: обов'язковий моніторинг трансфрормаційних процесів у світової господарській системі; необхідність максимального урахування всіх потреб учасників виробничої діяльності; відповідність регіональної інфрраструктури всім своїм фрункціям у виробничому процесі. 


\section{СПИСОК ВИКОРИСТАНИХ ДЖЕРЕЛ:}

1. Акмаєв А.І. Удосконалення оцінки конкурентоспроможності підприємства в умовах глобалізації. Культура народов Причерноморья. 2007. Вип. 99. С. 7-10.

2. Александрова О.В. Економічна стійкість сільськогосподарського виробництва як основний чинник його конкурентоспроможності. Збірник наукових праць Таврійського державного агротехнологічного універсиmemy. 2012. № 2. T. 3. С. 13-21.

3. Алексеенко Н.В. Устойчивое развитие предприятия как фрактор экономического роста. Економіка і організація управління. 2008. Вип. 3. С. 59-65.

4. Бугай В.З., Омельченко В.М. Analysis and evaluation of financial stability of the enterprise. Держава та регіони. 2008. № 1. С. 34-39.

5. Васильчак С.В. Економічна стійкість сільськогосподарських підприємств: стратегічний менеджмент. Формування ринкових відносин в Україні : збірник наукових праць / за ред. І.Г. Мансурова. Вид. 6(169). 2015. C. 67-70.

6. Mykola Kravchenko, Svitlana Khalatur, Kateryna Zhylenko, Yuliia Masiuk, Liudmyla Velychko. Assessment of bank lending diversi ficationin Ukraine. Banks and Bank Systems. 2018. № 13. P. 141-150.

\section{REFERENCES:}

1. Akmaiev A.I. (2007) Udoskonalennia otsinky konkurentospromozhnosti pidpryiemstva $v$ umovakh hlobalizatsii [Improvement of enterprise competitiveness assessment in the conditions of globalization]. Kultura narodov Prychernomoria, vol. 99, pp. 7-10.

2. Aleksandrova O.V. (2012) Ekonomichna stiikist silskohospodarskoho vyrobnytstva yak osnovnyi chynnyk yoho konkurentospromozhnosti [Economic sustainability of agricultural production as a major factor in its competitiveness]. Zbirnyk naukovykh prats Tavriiskoho derzhavnoho ahrotekhnolohichnoho universytetu, no. 2, t. 3, pp. 13-21.

3. Alekseenko N.V. (2008) Ustoichyvoe razvytye predpryiatyia kak faktor эkonomycheskoho rosta [Sustainable development of the enterprise as a factor of economic growth]. Ekonomika i orhanizatsiia upravlinnia: zb. nauk. pr., vol. 3, pp. 59-65.

4. Buhai V.Z., Omelchenko V.M. (2008) Analiz ta otsinka finansovoi stiikosti pidpryiemstva [Analysis and evaluation of financial stability of the enterprise]. Derzhava ta rehiony, no. 1, pp. 34-39.

5. Vasylchak S.V. Ekonomichna stiikist silskohospodarskykh pidpryiemstv: stratehichnyi menedzhment [Economic sustainability of agricultural enterprises: strategic management]. Formuvannia rynkovykh vidnosyn $v$ Ukraini, vol. 6(169), pp. 67-70.

6. Mykola Kravchenko, Svitlana Khalatur, Kateryna Zhylenko, Yuliia Masiuk, Liudmyla Velychko (2018) Assessment of bank lending diversi ficationin Ukraine. Banks and Bank Systems, no. 13, pp. 141-150. 